\title{
Evaluasi Reaksi Peserta Dalam Pelaksanaan Program Cool Class Di BTPN Syariah
}

\author{
Rahmi Citra Lestari Upara, ${ }^{\square}{ }^{\boxplus u l y a d i, ~ K u n t o ~ I m b a r ~ N u r s e t y o ~}{ }^{2}$ \\ ${ }^{1}$ Universitas Negeri Jakarta, Jakarta, Indonesia. \\ ${ }^{2}$ Universitas Negeri Jakarta, Jakarta, Indonesia. \\ 3 Universitas Negeri Jakarta, Jakarta, Indonesia. \\ DOI: https://doi.org/10.21009/JPI.o31.14
}

\begin{tabular}{l}
\hline Article History \\
\hline Received : 2020 \\
Accepted : 2020 \\
Published : 2020 \\
\hline Keywords \\
\hline Evaluation; Reaction; \\
Kirkpatrick; COOL \\
Class Program; BTPN \\
Syariah.
\end{tabular}

Syariah.

\begin{abstract}
Penelitian ini bertujuan untuk mengetahui reaksi peserta dalam pelaksanaan program COOL di BTPN Syariah. Evaluasi reaksi sangat penting untuk melihat sejauhmana tingkat kepuasan Community Officer sebagai peserta COOL Class. Adapun peneliti akan mengevaluasi reaksi dari 9 aspek yaitu pelatih/fasilitator, fasilitas, jadwal, media, metode, materi, konsumsi, latihan/tugas, dan studi kasus. Penelitian ini mengevaluasi reaksi peserta meggunakan model evaluasi menurut Donald L. Kirkpatrick pada level satu yaitu reaksi. Penelitian ini menggunakan 2 sumber data yaitu kuesioner dengan 48 responden dan wawancara dengan 1 responden. Pengumpulan data dilakukan dengan menyebarkan kuesioner dan melakukan wawancara. Hasil data menunjukkan bahwa peserta COOL puas terhadap program COOL Class yang dilaksanakan oleh BTPN Syariah. Hasil ini menunjukkan bahwa pelaksanaan program COOL Class memberi dampak positif bagi Community Officer. Hasil penelitian dapat dijadikan bahan evaluasi BTPN Syariah dalam penyelenggaraan program pelatihan selanjutnya.
\end{abstract}

\section{Abstract}

This study aims to find out the reaction of the participants in the implementation of COOL program at BTPN Syariah. Reaction evaluation is necessary to see how far the level of satisfication of Community Officer as COOL Class participants. The researcher evaluates the reaction from 9 aspects, namely the trainers/facilitators, facilities, schedules, media, methods, materials, consumption, exercises/assignments, and case studies. This study evaluates participants' reaction using evaluation model by Donald $L$. Kirkpatrick on level one, which is reaction. Data collection is done by using two data sources, which are quistionnaires for 48 participants and an interview with one respondent. The data show that COOL participants are satisfied with the implementation of COOL Class program at BTPN Syariah. These results indicate a positive impact in the implementation of COOL Class for Community Officer. The results of the study can be used as an evaluation material for BTPN Syariah in organizing future training programs. 


\section{PENDAHULUAN}

Persaingan bisnis global saat ini telah memberikan dampak yang signifikan bagi kelangsungan hidup perusahaan. Setiap perusahaan dituntut untuk selalu mengembangkan diri menjadi yang terbaik dari pesaing-pesaingnya. Perusahaan harus lebih mampu beradaptasi, mempunyai ketahanan, dan mampu melakukan perubahan arah dengan cepat agar perusahaan dapat tetap bertahan dan berkembang di tengah arus persaingan. Persaingan global ini yang menuntun perusahaan agar memiliki sumber daya manusia yang berkualitas sehingga dapat meningkatkan produktivitas perusahaan.

Menurut Noe, Sumber Daya Manusia (SDM) merupakan salah satu faktor kunci dalam menentukan keberlangsungan, efektivitas, dan daya saing dalam suatu perusahaan. ${ }^{1}$ SDM merupakan aset terbesar bagi perusahaan yang memegang peranan paling penting dan potensial bagi keberhasilan suatu perusahaan. Dalam setiap kegiatan perusahaan, tentunya didukung dengan sarana dan prasarana, serta sumber dana yang menjanjikan, namun tanpa dukungan SDM yang handal, kegiatan perusahaan tidak akan terselesaikan dengan baik. Hal ini menunjukkan bahwa SDM merupakan aset terbesar yang harus diperhatikan dengan segala kebutuhannya. SDM harus dikelola secara optimal, berkelanjutan dan diberi perhatian lebih guna memenuhi hak-haknya, dikarenakan SDM adalah mitra perusahaan untuk mencapai tujuan perusahaan.

Oleh karena itu, setiap perusahaan harus mempersiapkan program yang dapat meningkatkan kemampuan dan profesionalisme SDM agar perusahaan dapat bertahan dan berkembang sesuai dengan lingkungan perusahaan. Program yang banyak dilakukan oleh perusahaan untuk mengembangkan dan meningkatkan kualitas SDM adalah pelatihan. Pelatihan merupakan bentuk usaha yang dilakukan oleh perusahaan untuk meningkatkan kinerja para karyawannya. Tujuan dari program pelatihan ini adalah untuk meningkatkan kualitas kerja, ketrampilan, produktivitas kerja dan pengetahuan dari setiap karyawan sesuai dengan keinginan perusahaan. ${ }^{2}$

Pelatihan merupakan aspek yang sangat fundamental untuk diperhatikan dalam pengembangan SDM ataupun karyawan pada suatu perusahaan. Oleh sebab itu, pelatihan harus diatur secara efektif sesuai dengan kebutuhan perusahaan. Untuk membuat pelatihan karyawan menjadi efektif, ada beberapa hal yang harus dilakukan, misalnya menganalisis kebutuhan karyawan, menerapkan materi yang sesuai, adanya fasilitas yang memadai, mempunyai tujuan pelatihan yang jelas, memiliki instruktur yang mampu menjelaskan dengan baik, mengevaluasi program pelatihan tersebut, dan meningkatkan program pelatihan. ${ }^{3}$

Salah satu perusahaan yang menerapkan pelatihan untuk meningkatkan kinerja para karyawannya ialah PT. BTPN Syariah, Tbk. BTPN Syariah dibentuk melalui proses konversi PT Bank Sahabat Purba Danarta (Bank Sahabat) dan spin-off Unit Usaha Syariah PT Bank Tabungan Pensiunan Nasional Tbk (UUS BTPN), BTPN Syariah menjadi Bank Umum Syariah ke 12 di Indonesia. BTPN Syariah fokus pada segmen masyarakat berpenghasilan rendah atau pra-sejahtera. Fokus ini diwujudkan melalui sebuah produk yang disebut Pembiayaan Paket Masa Depan (PMD) yang merupakan program keuangan inklusif dengan membuka akses keuangan serta mensosialisasikan program edukasi literasi keuangan bagi segmen pra-sejahtera.

Community Officer merupakan karyawan BTPN Syariah yang bertugas untuk melayani nasabah segmen pra-sejahtera secara langsung. Community Officer tidak hanya berasal dari lulusan Si saja, bahkan mayoritas dari mereka merupakan lulusan SMA, D1 sampai D3. Seorang Community Officer diharapkan memiliki kemampuan komunikasi dan bernegosiasi yang baik untuk memberikan pemahaman terkait produk layanan kepada semua pihak terkait, dalam hal ini tidak hanya nasabah tetapi juga tokoh lokal setempat. Kemampuan tersebut perlu terus-menerus dilatih karena mereka akan selalu menghadapi situasi dan kondisi kasus yang berbeda setiap harinya dalam menangani nasabah. 
BTPN Syariah menyadari bahwa tidak ada tenaga siap pakai yang mengerti perbankan syariah sekaligus juga mengerti segmen prasejahtera produktif. Sehingga BTPN Syariah perlu menciptakan sendiri sumber daya manusia tersebut dengan memberikan pelatihan perbankan agar mereka mengerti mengenai dasar-dasar prinsip syariah dan perbankan secara umum, serta bagaimana pelayanan kepada segmen yang dituju. Selain itu, diperlukan tenaga yang handal, muda, dan cekatan untuk menjangkau daerah dengan letak geografis yang luas.

Berangkat dari kebutuhan-kebutuhan tersebut, BTPN Syariah melakukan penguatan kapasitas SDM khususnya bagi Community Officer melalui beberapa tahapan. Tahapan pertama yaitu Community Officer melakukan On the Job Training selama minimal 2 minggu dengan penempatan di seluruh MMS (Mobile Marketing Syariah) cabang BTPN Syariah. Tahap selanjutnya yaitu Community Officer belajar melalui aplikasi "COOL" yaitu program pelatihan online dengan sistem gamification; dimana karyawan baru dapat mempelajari proses-proses dasar akuisisi, pengelolaan dan pelayanan nasabah dengan cara yang menyenangkan yaitu Community Officer belajar melalui aplikasi. Tahapan yang terakhir ialah Community Officer mengikuti kelas program pelatihan atau yang disebut "COOL Class" yaitu pelatihan pengenalan pekerjaan atau program induksi selama 3 hari kelas pelatihan dengan metode pembelajaran aktif (active learning) menggunakan metode simulasi agar para calon Community Officer dapat melakukan pekerjaannya secara langsung.

Agar program pelatihan dapat studi yang berfokus pada memfasilitasi belajar dikatakan efektif maka harus dilakukan evaluasi dan meningkatkan kinerja. Salah satu intervensi untuk meminimalisir program dari kesalahan- teknologi pendidikan dalam meningkatkan kesalahan yang dimana nantinya akan dijadikan kinerja ialah dengan melakukan evaluasi. bahan perbaikan untuk program pelatihan yang Berdasarkan fakta-fakta tersebut dan belum akan datang. Berdasarkan hasil wawancara pada adanya evaluasi program yang dilakukan tanggal 10 April 2019 dengan Ibu terhadap program COOL Class di BTPN Syariah. Anggiearanidipta Suma Muhammadsjah selaku Hal tersebut mendorong peneliti sebagai Bussiness Learning Manager BTPN Syariah, teknolog pendidikan untuk melakukan evaluasi didapatkan informasi bahwa sejak awal reaksi peserta dalam pelaksanaan Program diadakan pada tahun 2018 belum ada evaluasi COOL Class yang diselenggarakan oleh BTPN program yang dilakukan terhadap efektivitas Syariah. Evaluasi tersebut dilakukan agar dapat program pelatihan COOL Class. Selain itu, mengetahui hasil pelaksanaan program COOL program ini belum pernah menggunakan model Class yang telah berlangsung melalui kepuasan evaluasi apapun dan tidak mempunyai peserta pelatihan.

indikator-indikator baku dalam mengukur program pelatihan yang telah dilaksanakan.

Evaluasi yang dilakukan hanya terbatas pada Keberhasilan sebuah program merupakan hal yang sangat penting mengingat yang diberikan dan telah menyerap dana besar selalu memberikan hasil yang efektif sesuai dengan tujuan program pelatihan yang ingin evaluasi sebagai tolak ukur untuk mengetahui sejauhmana keberhasilan suatu program pelatihan yang telah dilaksanakan sehingga hasil evaluasi tersebut dapat dijadikan masukan untuk program pelatihan selanjutnya.

Tingkat keefektivitasan suatu program pelatihan dapat diukur dari reaksi peserta efektif jika memberikan reaksi atau kesan yang positif terhadap peserta pelatihan. Namun bukan hanya reaksi positif saja, tapi juga untuk belajar dan berlatih. Selain itu, evaluasi ssi berguna untuk menunjang kemajuan terhadap pelatihan dapat dikaji oleh pihak penyelenggara agar dapat meningkatkan program pelatihan selanjutnya.

peserta pelatihan memberikan pengaruh yang karena peserta pelatihan adalah pihak yang merasakan dampak secara langsung dari program pelatihan. Sehingga reaksi peserta pelatihan merupakan hal yang penting bagi BTPN Syariah untuk melihat efektivitas dari program pelatihan yang dilaksanakan.

Teknologi pendidikan adalah program 


\section{METODE}

Metode penelitian ini merupakan penelitian evaluatif dengan metode survey. Penelitian survey adalah penelitian dengan tidak melakukan perubahan (tidak ada perlakuan khusus) terhadap variabel-variabel yang diteliti. Penelitian ini mengevaluasi reaksi peserta COOL terhadap pelaksanaan program COOL dengan menggunakan model evaluasi menurut Donald L. Kirkpatrick pada level satu yaitu reaksi.

Penelitian ini dilaksanakan di BTPN Syariah yang beralamat di Menara BTPN - CBD Mega Kuningan Jl. Dr. Ide Anak Gunung Gede Agung Kav. 5.5 5.6 Jakarta 12950. Adapun waktu penelitiannya dimulai dari bulan April 2019 Januari 2020.

Populasi pada penelitian ini adalah karyawan baru Community Officer berjumlah 48 orang dalam satu kelas sebagai sampel. Pelatihan dilaksanakan pada bulan Januari 2020. Teknik pengambilan sampel yang dilakukan dengan menggunakan sampling jenuh. Sampling jenuh adalah teknik penentuan sampel bila semua anggota populasi digunakan sebagai sampel.Untuk memperoleh data yang objektif, maka penelitian ini dilakukan dengan cara penyebaran kuesioner dan wawancara.

Data hasil evaluasi reaksi peserta COOL Class diperoleh berdasarkan penyebaran kuesioner. Semua data hasil penyebaran kuesioner selanjutnya dianalisis secara kuantitatif dengan menggunakan statistik deskriptif dengan teknik presentasi dengan rumus:

\section{$P=f / N \times 100 \%$}

Dengan keterangan sebagai berikut:

$\mathrm{P}=$ Hasil Jawaban

$\mathrm{f}=$ Frekuensi Jawaban

$\mathrm{N}=$ Jumlah Responden

Berdasarkan persentase yang didapat dari hasil perhitungan statisik deskriptif, peneliti mendeskripsikan hasil presentasi melalui narasi pada deskripsi data. Hasil perhitungan berupa presentasi dapat dikategorikan menurut kriteria sebagai berikut:

\begin{tabular}{cc}
\hline Persentase & Keterangan \\
\hline $\mathbf{0} \%$ & Tidak ada dari \\
$\mathbf{1} \%-<\mathbf{2 0} \%$ & Hampir sebagian \\
& kecil \\
$\mathbf{2 0}-<\mathbf{4 0} \%$ & Sebagian kecil \\
$\mathbf{4 0} \%-<\mathbf{5 0} \%$ & Kurang dari sebagian \\
$\mathbf{5 0} \%$ & Setengah dari \\
$\mathbf{5 0} \%-<\mathbf{6 0} \%$ & Lebih dari setengah \\
$\mathbf{6 0} \%-<\mathbf{8 0} \%$ & Sebagian besar \\
$\mathbf{8 0} \%-<\mathbf{1 0 0} \%$ & Hampir semua \\
$\mathbf{1 0 0} \%$ & Semua \\
\hline
\end{tabular}

\section{HASIL DAN PEMBAHASAN}

Berdasarkan deskripsi data yang diperoleh dari hasil penyebaran instrumen penelitian berupa kuesioner dan wawancara. Terdapat 25 pernyataan yang ada pada instrumen kuesioner dan 9 pertanyaan yang ada pada instrumen wawancara. Pada kedua instrumen tersebut terdapat 9 aspek yang dievaluasi pada Program Pelatihan COOL Class di BTPN Syariah yaitu pelatih/fasilitator, fasilitas, jadwal, media, metode, materi, konsumsi, latihan/tugas, dan studi kasus.

Berdasarkan deskripsi data yang diperoleh dari hasil penyebaran instrumen penelitian berupa kuesioner dan wawancara. Terdapat 25 pernyataan yang ada pada instrumen kuesioner dan 9 pertanyaan yang ada pada instrumen wawancara. Pada kedua instrumen tersebut terdapat 9 aspek yang dievaluasi pada Program Pelatihan COOL Class di BTPN Syariah yaitu pelatih/fasilitator, fasilitas, jadwal, media, metode, materi, konsumsi, latihan/tugas, dan studi kasus. Berikut merupakan analisis data dari hasil yang diperoleh:

\section{Pelatih/Fasilitator}

Terdapat 8 pernyataan untuk mengukur tingkat kepuasan peserta terhadap pelatih/fasilitator mencakup garis besar mengenai a) kemampuan komunikasi pelatih/fasilitator dalam menyampaikan informasi, b) kemampuan pelatih/fasilitator dalam penguasaan materi pelatihan, c) keterampilan pelatih/fasilitator dalam melibatkan peserta secara aktif dalam pelatihan. Berikut penjabaran hasil data yang diperoleh:

a. Kemampuan saat membuka pelatihan.

Pada data ini dapat diketahui bahwa sebagain besar peserta memberikan respon positif terhadap kemampuan komunikasi 
pelatih/fasilitator dalam membuka pelatihan. Hal tersebut dikarenakan pelatih/fasilitator dapat membuka pelatihan dengan baik yaitu mengucap salam, mengenalkan diri, dan memberikan wawasan terkait pelatihan (tujuan pelatihan, kegiatan, bentuk penugasan, aturan pelatihan) serta membangkitkan rasa ingin tahu peserta terhadap pelatihan.

b. Kemampuan saat menyajikan materi.

Pada data ini dapat diketahui bahwa hampir semua peserta memberikan respon positif terhadap kemampuan komunikasi pelatih/fasilitator dalam menyajikan materi dengan penilaian Baik. Hal tersebut dikarenakan pelatih/fasilitator memakai banyak versi penyajian materi seperti media presentasi, ceramah, simulasi, studi kasus maupun kerja kelompok.

c. Kemampuan saat menutup pelatihan dan memberikan evaluasi.

Pada data ini dapat diketahui bahwa sebagian besar peserta memberikan respon positif terhadap kemampuan pelatih/fasilitator saat menutup dan memberikan evaluasi pada akhir pembelajaran dengan penilaian Baik. Hal tersebut dikarenakan pelatih/fasilitator menutup pelatihan dengan baik yaitu memberikan ringkasan ataupun kesimpulan materi kemudian memberikan evaluasi berupa post test kepada peserta di setiap akhir sesi pelatihan.

d. Penguasaan substansi materi yang dimiliki pelatih/fasilitator.

Pada data ini dapat diketahui bahwa sebagian peserta memberikan respon positif terhadap kemampuan pelatih/fasilitator dalam menguasai subtasi materi dengan penilaian Sangat Baik. Hal tersebut dapat dilihat dari penguasaan materi yang dimiliki, pelatih mampu memberikan contoh maupun ilustrasi terkait materi. Selain itu mampu membantu peserta dalam memberikan jawaban maupun menemukan pemecahan masalah yang dihadapi oleh peserta.

Data tersebut sesuai dengan hasil wawancara kepada Learning Support Manager, diketahui bahwa pelatih/fasilitator diwajibkan untuk mengikuti Train sebelum mengajar di kelas COOL Class. selain itu, pelatih/fasilitator diwajibkan untuk mempelajari modulnya sebelum pelaksanaan pelatihan. Dengan kedua tahapam tersebut tentunya pelatih/fasilitator akan mampu menjawab pertanyaanpertanyaan peserta dengan sangat baik. Selain itu beliau menilai bahwa pelatih/fasilitator sudah sangat percaya diri yang mana dapat dilihat dari gesture tubuhnya dan kosa kata yang dipilih, hal tersebut menunjukkan bahwa mereka menguasai materi dengan sangat baik.

e. Menyampaikan materi secara bertahap (dari yang mudah ke sulit).

Pada data ini dapat diketahui bahwa lebih dari setengah peserta memberikan respon positif terhadap kemampuan pelatih/fasilitator dalam menyampaikan materi secara bertahap dengan penilaian Sangat Baik. Hal tersebut dapat dilihat dari cara penyampaian materi secara bertahap dari materi dasar kemudian materi yang lebih lanjut.

Berdasarkan wawancara dengan Learning Support Manager, diketahui bahwa pelatih/fasilitator diwajibkan untuk mempelajari modul sebelum pelaksanaan pelatihan sehingga nantinya mereka dapat menguasai urutan dalam penyampaian materi secara tepat.

f. Mendorong keterlibatan peserta untuk merespons/memberikan tanggapan.

Pada data ini dapat diketahui sebagian besar peserta memberikan respon positif terhadap kemampuan pelatih/fasilitator dalam mendorong keterlibatan peserta untuk merespons atau memberikan tanggapan dengan penilaian Sangat Baik. Hal tersebut dapat dilihat dari cara pelatih/fasilitator meminta peserta untuk bertanya, mengemukakan informasi, pengetahuan, ataupun pengalaman peserta. Contoh konkritnya pada pelatihan ini adalah para peserta dapat berdiskusi secara berkelompok untuk memecahkan masalah yang ditemui di lapangan berdasarkan pengalamannya sendiri. Sementara peran pelatih/fasilitator dalam diskusi tersebut ialah meluruskan pendapatpendapat para peserta serta memotivasi peserta untuk terlibat aktif dalam kelas.

Berdasarkan wawancara dengan Learning Support Manager, diketahui bahwa pelatih/fasilitator membangun partisipasi aktif peserta untuk aktif bertanya ataupun menanggapi dengan cara diskusi kelompok. Pelatih/fasilitator akan membentuk kelompokkelompok secara acak untuk mendukung proses pembelajaran yang berpusat pada peserta. Selain itu, peserta juga pelatih/fasilitator akan meluruskan pendapatpendapat para peserta. 
g. Mendorong keterlibatan peserta dengan menyelesaikan latihan atau tugas.

Pada data ini dapat diketahui sebagian besar peserta memberikan respon positif terhadap kemampuan pelatih/fasilitator dalam mendorong keterlibatan peserta untuk menyelesaikan latihan atau tugas dengan penilaian Sangat Baik. Hal tersebut dapat dilihat dari pemberian latihan/tugas di setiap akhir sesi pelatihan dan juga mendorong para peserta saling berkompetisi antar peserta dalam menyelesaikan latihan/tugas.

Berdasarkan wawancara dengan Learning Support Manager, diketahui bahwa pelatih/fasilitator mendorong para peserta untuk saling berkompetisi dalam menyelesaikan latihan/tugas. Peserta yang mengungguli dengan kriteria yaitu nilai tertinggi dan aktif pada saat pelatihan berlangsung akan mendapatkan reward berupa tumblr, sarung tangan, pouch, dan lain-lain.

h. Mendorong keterlibatan peserta melalui praktek simulasi.

Pada data ini dapat diketahui sebagian besar peserta memberikan respon positif terhadap kemampuan pelatih/fasilitator dalam mendorong keterlibatan peserta melalui praktek simulasi dengan penilaian Sangat Baik. Hal tersebut dapat dilihat dari pemberian praktek simulasi diantaranya simulasi prosedur kerja baik dari akuisisi nasabah sampai maintenance dengan bimbingan dan arahan dari pelatih/fasilitator.

Berdasarkan wawancara dengan Learning Support Manager, diketahui bahwa simulasi yang dilakukan ialah dengan memainkan peran seolah seperti di keadaan sebenarnya yang dibimbing langsung oleh pelatih/fasilitator. Salah satu simulasi yang dilakukan oleh para peserta ialah memerankan peran sebagai karyawan BTPN Syariah yaitu Community Officer itu sendiri, dan peserta lainya memerankan peran sebagai nasabah. Diharapkan dengan adanya simulasi, ketika nantinya mereka kembali ke penempatan kerja mereka masing-masing mereka sudah mempunyai pengalaman yang memadai seperti bagaimana menghadapi nasabah di lapangan.

Dari 8 analisis data yang telah dijabarkan, dapat disimpulkan bahwa pelatih/fasilitator yang terpilih sudah sangat baik dalam mengajarkan peserta pelatihan. Kemudian dikutip dari hasil wawancara dengan Support
Learning Manager, diketahui bahwa pelatih/fasilitator yang terpilih untuk mengajar COOL Class melalui proses beberapa tahap, yang pertama mereka harus mempelajari modul secara mendalam sebelum pelaksanaan pelatihan. Yang kedua mereka harus melewati tahap Train The Trainer (TTT) internal yaitu pelatihan untuk pelatih/fasilitator BTPN Syariah. Mereka sudah melalui tahap itu sehingga sudah dipastikan mereka sangat handal dan mumpuni saat mereka memberikan pelatihan kepada peserta.

\section{Fasilitas Pelatihan}

a. Tersedianya alat dan bahan yang memadai dalam menunjang pelatihan.

Pada data ini dapat diketahui sebagian besar peserta memberikan respon positif terhadap Tersedianya alat dan bahan yang memadai dalam menunjang pelatihan dengan penilaian Sangat Setuju.

b. Ruang kelas dalam keadaan baik dan nyaman dalam menunjang pelatihan.

Pada data ini dapat diketahui sebagian besar peserta memberikan respon positif terhadap ruang kelas dalam keadaan baik dan nyaman dalam menunjang pelatihan dengan penilaian sangat setuju.

c. Suhu ruangan kelas diatur dengan baik dalam menunjang pelatihan.

Pada data ini dapat diketahui setengah dari peserta memberikan respon positif terhadap Suhu ruangan kelas diatur dengan baik dalam menunjang pelatihan dengan penilaian setuju.

Berdasarkan wawancara dengan Support Learning Manager, diketahui bahwa alat dan bahan sudah sangat memadai dalam menunjang pelatihan, namun untuk kelas pelatihan masih kurang baik dikarenakan ruangan yang kurang luas sehingga membatasi kegiatan pelatihan yang telah direncanakan oleh penyelenggara pelatihan atau biasa disebut Learning Support di BTPN Syariah.

\section{Jadwal Kegiatan Pelatihan}

a. Alokasi waktu pelaksanaan pelatihan sesuai dengan jadwal yang telah ditentukan.

Pada data ini dapat diketahui sebagian besar peserta memberikan respon positif terhadap alokasi waktu pelaksanaan pelatihan sesuai dengan jadwal yang telah ditentukan dengan penilaian setuju. Namun terdapat hampir sebagian kecil peserta memberikan respon negatif dengan penilaian kurang setuju. 
Hal tersebut dikarenakan terkadang durasi pelatihan melebihi jadwal yang telah ditentukan. Alasannya adalah dari hasil wawancara dengan Support Learning Manager, menyebutkan peserta sangat tertarik dengan kegiatan pelatihan sehingga terkadang melebihi durasi waktu pelatihan yang telah ditentukan.

b. Waktu istirahat yang diberikan cukup untuk peserta.

Pada data ini dapat diketahui sebagian besar peserta memberikan respon positif terhadap waktu istirahat yang diberikan cukup untuk peserta dengan penilaian sangat setuju. Berdasarkan wawancara dengan Learning Support Manager, diketahui bahwa waktu istirahat yang diberikan sangat baik yaitu sebanyak $3 \mathrm{x}$ istirahat di pagi, siang, dan malam hari. Selain itu menyediakan coffee break (snack) sebanyak 2x.

\section{Media}

a. Media yang digunakan membantu peserta dalam memahami materi pelatihan.

Pada data ini dapat diketahui sebagian besar peserta memberikan respon positif terhadap Media yang digunakan membantu peserta dalam memahami materi pelatihan dengan penilaian sangat setuju.

b. Media yang digunakan meningkatkan minat belajar peserta.

Pada data ini dapat diketahui setengah dari peserta memberikan penilaian sangat setuju dan setengah dari peserta memberikan penilaian setuju terhadap media yang digunakan membantu peserta dalam memahami materi pelatihan.

Berdasarkan wawancara dengan Learning Support Manager, menyebutkan bahwa media sangat membantu peserta dalam memudahkan peserta dalam memahami materi, contohnya seperti penggunaan media presentasi/powerpoint. Selain itu, penggunaan poster dapat meningkatkan minat belajar peserta karena peserta didorong untuk aktif dalam pembelajaran dengan cara menjelaskan poster dan ada juga yang bertanya.

\section{Metode}

a. Metode yang digunakan sesuai dengan tujuan pelatihan.

Pada data ini dapat diketahui sebagian besar peserta memberikan respon positif terhadap metode yang digunakan sesuai dengan tujuan pelatihan dengan penilaian sangat setuju.

b. Metode yang digunakan mudah dipahami peserta

Pada data ini dapat diketahui hampir semua peserta memberikan respon positif terhadap Pada data ini dapat diketahui sebagian besar peserta memberikan respon positif terhadap metode yang digunakan sesuai dengan tujuan pelatihan dengan penilaian sangat setuju.

Berdasarkan wawancara dengan Learning Support Manager, diketahui bahwa metode yang digunakan sangat mendorong keterlibatan peserta secara aktif dengan $40 \%$ teori dan $60 \%$ praktek. Peserta lebih didorong untuk melakukan praktek dan dapat berinteraksi dengan peserta lainnya dengan berbagai metode seperti simulasi, diskusi, dan kerja kelompok.

Pelatihan COOL Class mengutamakan metode simulasi dalam pembelajaran agar para Community Officer dapat mempraktekkan pekerjaannya secara langsung. Simulasi yang diberikan yaitu prosedur kerja dari akuisisi nasabah sampai maintenance. Dengan keterlibatan secara langsung peserta dapat belajar lebih cepat dan memahaminya lebih lama.

Hal tersebut sesuai dengan hasil wawancara kepada Learning Support Manager, diketahui bahwa metode yang digunakan mampu menciptakan suasana pelatihan yang menarik dan kreatif yaitu dengan diskusi, kerja kelompok, dan simulasi sehingga pembelajaran menjadi menarik dan dapat meningkatkan minat belajar peserta.

\section{Materi}

a. Materi yang disampaikan sesuai dengan tujuan pelatihan.

Pada data ini dapat diketahui sebagian besar peserta memberikan respon positif terhadap materi yang disampaikan sesuai dengan tujuan pelatihan dengan penilaian sangat setuju.

b. Materi yang disampaikan sesuai dengan kebutuhan peserta.

Pada data ini dapat diketahui hampir semua peserta memberikan respon positif terhadap Materi yang disampaikan sesuai dengan kebutuhan peserta dengan penilaian sangat setuju. 
Berdasarkan wawancara dengan Learning Support Manager, diketahui bahwa materi pelatihan disusun untuk sesuai dengan kebutuhan mereka di lapangan. Sehingga jika peserta belajar dengan baik, sudah dipastikan peserta dapat mengaplikasikannya di lapangan.

\section{Konsumsi}

a. Konsumsi yang diberikan mencukupi dan memiliki kualitas yang bagus untuk para peserta.

Pada data ini dapat diketahui lebih dari setengah peserta memberikan respon positif terhadap konsumsi yang diberikan mencukupi dan memiliki kualitas yang bagus untuk para peserta dengan penilaian sangat setuju.

Berdasarkan wawancara dengan Support Learning Manager, diketahui jumlah dan kualitas konsumsi disediakan sudah sangat baik. Pihak BTPN Syariah menyediakan makanan dan minuman sebanyak $3 \mathrm{x}$ untuk makanan berat di pagi, siang, dan malam hari. Selain itu, menyediakan coffee break (snack) sebanyak $2 \mathrm{x}$.

\section{Latihan atau Tugas}

a. Latihan atau tugas yang diberikan sesuai dengan materi pelatihan

Pada data ini dapat diketahui hampir semua peserta memberikan respon positif terhadap Latihan atau tugas yang diberikan sesuai dengan materi pelatihan dengan penilaian sangat setuju.

b. Latihan atau tugas yang diberikan bermanfaat bagi peserta dalam melakukan jobdesk

Pada data ini dapat diketahui hampir semua peserta memberikan respon positif terhadap latihan atau tugas yang diberikan bermanfaat bagi peserta dalam melakukan jobdesk dengan penilaian sangat setuju.

Berdasarkan wawancara dengan Learning Support Manager, diketahui bahwa latihan atau tugas yang diberikan kepada peserta ialah dengan mengerjakan LSWAP yaitu Lembar Survey Wawancara dan Analisa Pembiayaan. Dengan pemberian latihan ataupun tugas tersebut diharapkan peserta dapat terlatih ketika nantinya bekerja langsung di lapangan. Post test tersebut diantaranya ialah latihan dan tes mengerjakan LSWAP, post test basic TUR, dan post test Mandatori. Selain itu biasanya pelatih/fasilitator memberikan tugas perharinya kepada peserta agar membaca materi yang akan dibahas keesokan harinya.

\section{Studi Kasus}

a. Studi kasus yang diberikan sesuai dengan materi pelatihan

Pada data ini dapat diketahui hampir semua peserta memberikan respon positif terhadap studi kasus yang diberikan sesuai dengan materi pelatihan dengan penilaian sangat setuju.

b. Studi kasus yang diberikan bermanfaat bagi peserta dalam melakukan jobdesk

Pada data ini dapat diketahui hampir semua peserta memberikan respon positif terhadap studi kasus yang diberikan sesuai dengan materi pelatihan dengan penilaian sangat setuju.

Studi kasus yang diberikan tentunya sudah sesuai dengan materi pelatihan yang nantinya diharapkan dapat bermanfaat bagi peserta dalam melakukan pekerjaannya sebagai Community Officer dengan optimal. Berdasarkan wawancara dengan Learning Support Manager, diketahui bahwa studi kasus yang diberikan kepada peserta ialah dapat berasal dari pengalaman ataupun masalah yang dialami oleh peserta selama OJT di lapangan. Peserta diminta untuk mengidentifikasi masalah, menganalisa situasi dan merumuskan penyelesaian-penyelesaian alternatif.

\section{SIMPULAN}

Pada penelitian ini peneliti ingin menilai reaksi peserta program COOL Class dikarenakan reaksi peserta merupakan hal yang penting bagi perusahaan untuk melihat efektivitas dari program pelatihan yang dilaksanakan. Berdasarkan hasil penelitian dan analisis data pada program pelatihan "COOL Class untuk karyawan Community Officer" maka dapat diambil kesimpulan bahwa diperoleh ada kecendurungan di setiap komponen sebagian besar direspon positif oleh peserta pelatihan yang terdiri dari komponen pelatih/fasilitator, media, metode, materi, konsumsi, latihan/tugas, dan studi kasus. Namun pada beberapa komponen terdapat aspek yang memiliki penilaian yang rendah diantaranya aspek jadwal pelatihan dan fasilitas pelatihan. 


\section{UCAPAN TERIMA KASIH}

Peneliti mengucapkan terimakasih kepada pihak BTPN Syariah yang telah memberikan izin untuk melakukan penelitian dan terimakasih untuk Ibu Anggiearanidipta Suma Muhammadsjah selaku Bussiness Learning Manager BTPN Syariah yang telah banyak membantu saya dalam penelitian yang saya lakukan. Peneliti juga mengucapkan terimakasih kepada Bapak Drs. Mulyadi M. Pd sebagai dosen pembimbing 1 dan Bapak Kunto Imbar Nursetyo, M.Pd sebagai dosen pembimbing 2 yang telah meluangkan waktunya untuk memberikan bimbingan kepada saya.

\section{DAFTAR PUSTAKA}

Atwi, P. d. (1999). Evaluasi Program Diklat. Jakarta: Sekolah Tinggi Ilmu Administrasi Negara-LAN.

Jabar, S. A. (2004). Evaluasi Program Pendidikan-Pedoman Teoritis Praktis bagi Praktisi Pendidikan. Jakarta: Bumi Aksara.

Kaswan. (2011). Pelatihan dan Pengembangan Untuk Meningkatkan Kinerja SDM. Bandung: Alfabeta.

Kaswan, M. (2012). Manajemen Sumber Daya Manusia Untuk Keunggulan Bersaing Organisasi . Yogyakarta: Graha Ilmu.

Mathis L. Robert, J. H. (2002). Sumber Daya Manusia. Jakarta: PT Salemba Empat.

Sedarmayanti. (2013). Manajemen Sumber Daya Manusia, Reformasi Birokrasi, dan Manajemen Pegawai Negeri Sipil, cetakan keenam. Bandung: PT Refika Aditama.

Sendarmayanti. (2007). Manajemen Sumber Daya Manusia. Bandung: Refika Aditma.

Sudarmanto. (2014). Kinerja dan Pengembangan Kompetensi SDM (Teori, Dimensi, Pengukuran dan Implementasi dalam Organisasi. Yogyakarta: Pustaka Belajar.

Suwatno, P. D. (2016). Manajemen SDM dalam organisasi Publik dan Bisnis . Bandung: CV Alfabeta.

Tayibnapis, F. Y. (200o). Evaluasi Program. Jakarta: Rineka Cipta.

Triyono, A. (2012). Paradigma Baru Manajemen Sumber Daya Manusia . Yogyakarta: ORYZA.
Widodo, S. E. (2017). Manajemen Pengembangan Sumber Daya Manusia. Jakarta: Jaya Media .

(2019, Juli 5). Retrieved from BTPN Syariah : https://www.btpnsyariah.com/tentang -kami/profil.html

Sukardi. 2014. Evaluasi Program Pendidikan dan Kepelatihan. Jakarta: Bumi Aksara.

Purwanto dan Suparman Atwi (1999), Evaluasi Program Diklat, Jakarta: Sekolah Tinggi Ilmu Administrasi Negara-LAN

Jack J Philips. 2002. How To Measure Training Results. New York; Mc Graw Hill

Donald L. Kirkpatrick dan James D. Kirkpatrick. 2006. Evaluating Training Programs (San Frasisco: BerrettKoehler Publisher).

Yusufhadi Miarso. 2004. Menyemai Benih Teknologi Pendidikan. Jakarta: Kencana.

Peraturan Lembaga Administasi Negara (LAN) nomor 5 tahun 2008

Uno, Hamzah B. 2008. Perencanaan Pembalajaran. Jakarta: Bumi Aksara

Panduan Paket Masa Depan, Edisi Revisi tahun 2012, 2012 (Jakarta: BTPN Syariah) 